\title{
EMPIRICAL RESEARCH AND THE SHAREHOLDER DERIVATIVE SUIT: TOWARD A BETTER-INFORMED DEBATE
}

\author{
BRYant G. Garth,* \\ ILENE H. NAGEL, $\dagger$ \\ AND \\ Sheldon J. Plager**
}

I

\section{INTRODUCTION AND OVERVIEW}

The derivative suit has been called "the chief regulator of corporate management," but recent writings employing economic theories of the firm directly challenge this assertion. It has been said that "very little of any value would be lost by outright abolition of the legal duty of care [of corporate managers] and its accompanying threat of a [derivative] lawsuit." 2 Yet, despite repeated legislative, judicial, and scholarly assaults, the derivative suit has managed to survive for well over one hundred years. ${ }^{3}$ The purpose of this article is to explore how social science research might answer some of the recurring questions raised about the role of shareholder derivative suits.

In this introduction we identify in general terms the factors that give rise to the derivative suit and the criticisms that shareholder actions engender. We then review in part II the existing empirically focused literature on the subject and assess the extent of knowledge about derivative suits. In part III we offer several models for empirical research which might be particularly useful in increasing this body of knowledge and in providing significant new insight into the issues identified in part I. Part IV then concludes by recognizing some of the limitations of empirical research.

\footnotetext{
Copyright (C) 1985 by Law and Contemporary Problems

* Associate Professor, Indiana University School of Law (Bloomington) and Louis F. Neizer Faculty Fellow.

$\dagger$ Professor, Indiana University School of Law (Bloomington).

** Professor, Indiana University School of Law (Bloomington).

1. Cohen v. Beneficial Indus. Loan Corp., 337 U.S. 541,548 (1949).

2. Scott, Corporation Law and the American Law Institute Corporate Governance Project, 35 STAN. L. Rev. 927,937 (1983) (arguing for retaining the derivative suit primarily in duty of loyalty cases, but not in duty of care cases).

3. See Coffee \& Schwartz, The Survival of the Derivative Suit: An Evaluation and a Proposal for Legislative Reform, 81 Colum. L. Rev. 261, 261 n.2 (1981) (dating the American origin to the 1856 case of Dodge v. Woolsey, 59 U.S. (18 How.) 331).
} 
When ownership and control of a corporate enterprise are united in the same persons, there is little need for the derivative suit as a corrective. Violations of the manager's "duty of care" will impose any direct economic consequences directly on the violator: no one need sue. Policy conflicts with the larger society may of course arise. While many believe that free enterprise is best encouraged through profit maximization, others perceive a concept of the public good that requires the modern business firm to have goals beyond or in addition to that. These issues raise broad questions of accountability, but in a context in which derivative suits appear to have limited utility. ${ }^{4}$

When control and investment are separated, as is so often the case in the modern business corporation, the accountability of management to the shareholders becomes a central concern. ${ }^{5}$ This concern is triggered by, but not limited to, the shareholders' narrow pecuniary interest: it implicates notions of mutuality of consent, of fair dealing, and of moral responsibility to those over whom or over whose interests one has power. In this context the responsibilities of the corporate manager are often cast in terms of fiduciary duties-duties which historically have arisen out of relationships of trust and confidence. ${ }^{6}$

While the ideal of shareholder democracy inspires few in today's world, there remain persons who believe in strengthening the rights of shareholders to monitor managerial conduct. In the relatively few years since the shareholder derivative suit was introduced into American jurisprudence, the struggle for power between managers and shareholders has been played out both in the courts and in the legislatures. A brief review of this struggle, reflected in the history of the derivative suit, will highlight the major areas in which the battles have been fought and will provide a sense of the issues which need to be considered empirically.

The shareholder derivative suit is a special form of class action, since the plaintiff shareholder theoretically acts to represent the interests of all shareholders-in effect, the interests of the corporation itself. Under the Federal Rules of Civil Procedure, these actions were originally treated under Rule 23 as a species of class actions generally. The 1966 revisions created Rule 23.1, a separate rule governing derivative suits. ${ }^{7}$ The new rule, however,

4. For example, Scott, supra note 2, at $932 \mathrm{n} .21$, argues that suits challenging payments made for a company's benefit without receipt by managment of any part of the proceeds, but made contrary to some relatively specific prohibition-foreign bribery, for example-should be viewed as based on an implied private cause of action for civil damages, aimed at enforcement of the particular legal rule. Such suits should not be grounded on a supposed fiduciary breach inhering in a decision that might have been quite reasonably calculated to advance shareholders' interests.

5. See generally Comment, Shareholders' Derivative Suits and Shareholders' Welfare: An Evaluation and a Proposal, 77 Nw. U.L. REv. 856 (1982).

6. See, e.g., Goldstein v. Groesbeck, 142 F.2d 422, 425 (2d Cir.) (A derivative action “in essence is nothing more than a suit by a beneficiary of a fiduciary to enforce a right running to the fiduciary as such."), cert. denied, 323 U.S. 737 (1944).

7. See generally 7A C. Wright \& A. Miller, Federal Practice and Procedure $\$ 1821-1841$ (1972 \& 1984 Supp.). 
essentially incorporates the prior law. ${ }^{8}$ The shareholder continues to sue to enforce a claim that technically belongs to the corporation. ${ }^{9}$ The corporation must be joined as a party, and the relief granted is a judgment against third persons, also named as defendants, in favor of the corporation. ${ }^{10}$ The plaintiff as such recovers nothing. The rules governing state practice vary, ${ }^{11}$ but the basic process remains the same.

The emergence of the derivative suit as a major threat to unquestioned control of the business enterprise by corporate management has not gone unchallenged. The challenges have not been motivated simply by venal selfinterest of managerial power-wielders. Managers understandably may question procedures that, in the risk-laden atmosphere of high finance and corporate business venture, could hold them to an ex post facto measure of the reasonableness of their judgments. Even in cases of self-dealing, when the manager's devotion to his own interests might conflict with his loyalty to the corporation, it is not always clear that the expense-in dollars and in the corporation's reputation for soundness as an investment-is worth the often illusory or de minimis compensation the shareholders received or the questionable deterrent effect from which society theoretically benefited. If the business of business is business, should either minority shareholders or courts, far removed from the pressures of meeting a payroll, review the business judgment of those charged with making the tough decisions, using a standard of moral conduct not generally adhered to by the business community itself?

It is not surprising then that an array of procedural hurdles developed in connection with the derivative suit. One hurdle often encountered is the contemporaneous-share-ownership rule-the requirement that the shareholder have owned his shares at the time of the alleged wrong. ${ }^{12}$ Other related limitations on standing concern shareholders who hold only beneficial interests or who hold hybrid interests such as convertible debentures. These heel-nipping constraints have not prevented the derivative suit from flourishing, however, in part because such suits are a potential gold mine for plaintiffs' attorneys, who in effect become the real parties in interest in some of the derivative suits. ${ }^{13}$

8. Federal court requirements for a shareholder suit include among other things a verified complaint, limitations on standing, a demand on directors or reasonable excuse for not making such demand, and an allegation that the suit is not a collusive one to confer federal jurisdiction. $1 R$. Magnuson, Shareholder Litigation $\$ 8.03$ (1984).

9. Because the action is "derivative," the plaintiff has a claim only as good as that of the corporation on whose behalf he sues. Therefore the corporation itself must have a cause of action which it could enforce if it so desired. 1 R. MAgnuson, supra note $8, \S 8.04$. See generally Ross v. Bernhard, 396 U.S. 531 (1970) (right to jury trial in derivative suit is determined by rights of the corporation, not those of the shareholder plaintiffs).

10. See 1 R. Magnuson, supra note $8, \S 8.23$.

11. See id. $\$ 8.02$.

12. See generally H. Henn \& J. Alexander, Laws of Corporations $\$ 362$ (3d ed. 1983).

13. See Scott, supra note 2 , at 940 . The suing stockholder becomes a nominal or figurehead plaintiff. Id. For a discussion of the attorney's potential conflict of interest, the role of the 
Following a study of the derivative suit for the Chamber of Commerce of the State of New York in the mid-1940's, state security-for-expenses statutes became widespread. ${ }^{14}$ It was believed that such laws would discourage nonmeritorious actions. ${ }^{15}$ While these statutes may have curtailed actions, there was nothing in the statutory requirement to distinguish between actions which were meritorious and those which were not. ${ }^{16}$ Over time, the shift of power back to the corporate managers provided by these statutes was countered by sophisticated plaintiffs, who asserted a federal cause of action, to which the courts have held the state statutes inapplicable, or who filed in states with no such statute, or who employed other now well-recognized evasive devices. ${ }^{17}$

Perhaps the most powerful legal doctrine currently available to corporate management to protect its control position is the business judgment rule. ${ }^{18}$ When this rule is coupled with the requirement that a potential plaintiff in a derivative suit first exhaust any intracorporate remedy by making demand that the board of directors right the alleged wrong to the corporate polity, management is equipped with a powerful weapon. ${ }^{19}$ If pursuing the proposed suit is not in the best business interest of the corporation (and by necessary inference, the shareholders), then by definition it is not a suit for the benefit of the corporation and should be dismissed. ${ }^{20}$ The logic is more compelling when the issue is the manager's duty of care rather than his duty of loyalty, ${ }^{21}$ but the cases do not consistently turn on this distinction.

Demand is generally excused when the directors and managers making the business judgment are themselves implicated in the alleged wrongdoing. ${ }^{22}$ Hence emerges the latest counterthrust: the committee of independent directors whose business judgment is not tainted by self-interest. ${ }^{23}$ The standards governing the use of this device are still developing. The Delaware Supreme Court, in the widely discussed case of Zapata Corp. v. Maldonado, ${ }^{24}$

substantial fee award, and the dangers of collusive settlements, see Coffee \& Schwartz, supra note 3, at $318-20$.

14. The study is discussed infra at notes 30-38 and accompanying text. The typical statute requires a plaintiff to post a bond as security for payment of the defendant's reasonable expenses, including attorney fees, in defending the derivative suit. $1 \mathrm{R}$. Magnuson, supra note 8, $\$ 8.13$.

15. See Note, Security for Expenses in Shareholders' Derivative Suits: 23 Years' Experience, 4 Colum. J.L. \& Soc. Probs. 50, 52-53 (1968).

16. See id. at 66.

17. See generally id. at 59-64.

18. See, e.g., Cox, Searching for the Corporation's Voice in Derivative Suit Litigation: A Critique of Zapata and the ALI Project, 1982 Duke L.J. 959; Steinberg, Application of the Business Judgment Rule and Related Judicial Principles-Reflections from a Corporate Accountability Perspective, 56 Notre Dame Law. 903 (1981).

19. See, e.g., Joy v. North, 692 F.2d 880, 887 (2d Cir. 1982), cert. denied, 460 U.S. 1051 (1983).

20. See Burks v. Lasker, 441 U.S. 471, 485 (1979) (offensive application of the business judgment rule); Joy v. North, 692 F.2d 880, 893 (2d Cir. 1982), cert. denied, 460 U.S. 1051 (1983).

21. See Scott, supra note 2, at 937.

22. See, e.g., Joy v. North, 692 F.2d 880, 887-88 (2d Cir. 1982), cert. denied, 460 U.S. 1051 (1983).

23. See Note, Director Independence and Derivative Suit Settlements, 1983 Duke L.J. 645; Comment, Director Judge Thyself-The "Independent" Director and Dismissal of a Shareholder Suit in Lewis v. Anderson, 1980 Utah L. Rev. 601; Recent Development, Business Judgment Dismissal of Shareholder Derivative Suits by Board Litigation Committees: An Expanded Role for the Courts, 35 VAND. L. Rev. 235, 256-57 (1982).

24. 430 A.2d 779 (Del. 1981). 
applied a new two-step test for evaluating a corporation's motion to dismiss a shareholder derivative suit, based on the recommendation of an allegedly independent committee of directors. First, the court placed the burden on the corporation to demonstrate the good faith, independence, and reasonableness of the committee. ${ }^{25}$ Second, the court, using its own business judgment, assessed independently whether dismissal would be appropriate. ${ }^{26}$ There have been suggestions that this test goes too far in second-guessing corporate business judgments. ${ }^{27}$ The American Law Institute, on the other hand, takes the position that suits against controlling persons which allege self-dealing should not be terminated by an action or recommendation of those representing the corporation itself. ${ }^{28}$ What is clear is that a lively debate has emerged, and the relevant litigating constituencies believe that a new stage-a new balance of power-is developing.

How do these thrusts and parries actually work? Do they really matter? Are the legal constructs effective in the board rooms-or back rooms-of business? Are wrongdoers deterred? Is there such a person as an "independent" director, on whom anyone could rely, or is the fabric of corporate power so closely woven that anyone inside is, if not financially at least psychologically, an insider? ${ }^{29}$ These and many other questions are being asked; this article focuses on ways in which empirical research can help clarify the answers.

\section{II}

\section{A Review of the Available Empirical Research}

At this writing, we know of only four published studies of the shareholder derivative suit based on empirical research. We shall examine these studies for three reasons. First, they tell us what we do know about the derivative action as it operates in practice, thus beginning the task of mapping out its present role. Second, they illustrate some of the problems in attempting to resolve key issues that divide scholars and commentators. Finally, these studies point the way to new empirical research which may be capable of shedding further light on this kind of law enforcement through private litigation.

25. Id. at 788 .

26. Id. at 789 .

27. See Recent Development, supra note 23, at 259-61 (criticizing second step as irrelevant); $c$. Cox \& Schwartz, The Business Judgment Rule in the Context of Termination of Derivative Suits by Independent Committees, 61 N.C.L. REv. 541,545 (1983) (danger that Zapata rule "conscripts the corporation to vindicate the public interest").

28. Cox \& Schwartz, supra note 27, at 547; see also Principles of Corporate Governance and Structure: Restatement and Recommendations § 7.03(c)(iii) (Tent. Draft No. 1, 1982).

29. See Cox \& Munsinger, Bias in the Boardroom: Psychological Foundations and Legal Implications of Corporate Cohesion, LAW \& Contemp. Probs., Summer 1985, at 83. 


\section{A. The Wood Study (1944)}

The earliest empirically based study reached conclusions quite critical of derivative suits. Wood's Survey and Report Regarding Stockholders' Derivative Suits, prepared for the Chamber of Commerce of the State of New York, covered all such lawsuits filed between 1932 and 1942 in the Supreme Court of New York County and the U.S. District Court for the Southern District of New York, as well as those filed between 1938 and 1942 in the Supreme Court of Kings County. ${ }^{30}$ Wood found 1128 derivative suits in New York County, 142 in Kings County, and 130 in the U.S. district court; the flow remained essentially constant over the period studied. ${ }^{31}$ The bulk of Wood's analysis dealt with the $\mathbf{5 7 3}$ derivative suits he found involving publicly held corporations. ${ }^{32}$

Wood's focus was on how the suits arose, what results were obtained, and the size of attorney fees generated. The reported findings support his strongly negative conclusions. Noting that about sixty percent of the "more substantial cases" were brought by a small group of attorneys and law firms, ${ }^{33}$ and that the representative plaintiffs had very small stakes in the outcome, ${ }^{34}$ he suggested that the members of the bar bringing such suits made "the ambulance-chaser by comparison a paragon of propriety." 35

Wood concluded that the results in the suits involving publicly held corporations were not, in any event, very favorable to the plaintiffs. He found, for example, only 13 judgments with recoveries for plaintiffs, 33 courtapproved settlements, 60 private settlements, 215 dismissals, and 155 discontinuances, with the remaining filings either pending or not recorded. ${ }^{36}$ Only forty-six of these cases clearly resulted in gains to the plaintiffs. ${ }^{37}$ In those reported settlements, however, the recoveries were substantial-mostly well over $\$ 100,000^{38}$-as were the attorney (and accountant) fees, which tended to amount to about one-fourth of the recovery. ${ }^{39}$ Top fees of $\$ 795,000$ were awarded in one litigated suit. ${ }^{40}$ Success, Wood emphasized, meant prosperity for the lawyers. ${ }^{41}$ Wood also deplored the fact, established by an analysis of the cases favorable to plaintiffs, that most of the violations were merely technical, without any showing of bad faith, and the per share value of the recoveries was usually well under a dollar. ${ }^{42}$ His conclusions thus

30. F. Wood, Survey and Report Regarding Stockholders' Derivative Suits 1-3 (1944).

31. Id. at 3-5. But of. id. at 32 (greater variance apparent when cases grouped into "closely held corporations"/"publicly held corporations" categories).

32. See id. at $32 \&$ passim.

33. Id. at 57.

34. Id. at 46 .

35. Id. at 47.

36. Id. at 32 .

37. See id.

38. Id. at 51-53.

39. See id.

40. Id. at 50.

41. See id. at 112 .

42. Id. at 9, 50-53. 
led to a call for reform, culminating in widespread adoption of the requirement of security for expenses in derivative suits. ${ }^{43}$

\section{B. The Kennedy Study (1977)}

Derivative suits received much less attention, both empirical and theoretical, after the round of reform in the 1940's. The more recent empirical studies, in fact, really focus elsewhere: on the class action. With the revision of Rule 23 of the Federal Rules of Civil Procedure in 1966, which created a new kind of class action for damages (Rule 23(b)(3)) and gave the derivative action its own separate rule, Rule $23.1,{ }^{44}$ plaintiffs alleging securities violations gained another very controversial weapon. The controversy surrounding class actions for damages has led investigators interested in federal securities law to concentrate much more on class actions than on derivative suits. Issues related especially to the derivative action have therefore not received much attention. The problem is compounded for researchers interested in the derivative action since, while derivative and class actions are conceptually distinct, it is not at all unusual to have a lawsuit that alleges both derivative claims redounding theoretically to the corporation's benefit and class claims asserted on behalf of the shareholders. We shall term these mixed suits, which appear in all the recent studies, "class/derivative."

Kennedy's study ${ }^{45}$ typifies an original concern with the class action for damages; ${ }^{46}$ he picked the securities field merely as an example. He first searched for all the securities class actions filed between January 1, 1966, and July 1,1973 , in the U.S. district court in Dallas. ${ }^{47}$ This search yielded a total of twenty-seven class actions. ${ }^{48}$ After interviews with attorneys suggested some important connections to derivative and class/derivative actions, he went back and found another twenty-nine cases. ${ }^{49}$ The ultimate sample from which he collected the relevant data thus became: twenty-two pure class, twenty-three mixed class/derivative, and nine pure derivative suits. ${ }^{50}$ The report contains useful information; unfortunately, however, the categories are sometimes lumped together in Kennedy's discussion.

Kennedy's research involved some interviews about how the lawsuits got started, but his questions referred only to the securities class actions.51 Nevertheless, as he observed, the responses to the question he asked-“"What were the controlling factors in the choice to bring this action as a class action

43. See id. at 17-26 (calling for such legislation).

44. See Fed. R. Civ. P. 23.1 (advisory committee note).

45. Kennedy, Securities Class and Derivative Actions in the United States District Court for the Northern District of Texas: An Empirical Study, 14 Hous. L. REv. 769 (1977).

46. Id. at 796-97.

47. Id. at 797 .

48. Id. at 799 .

49. Id. .

50. Id. at 803 (table 2 indicates that the total was reduced from 56 by two formal consolidations).

51. Id. at 799 . 
rather than as an individual action?"52-could be instructive for understanding both class and derivative suits. All that could be determined from the limited sample of fifteen interviews, however, was that "plaintiffs' lawyers think very specifically in terms of actual and projected time and money investments in the suit, while defendants' attorneys think of the cost to defend and the total liability exposure." 53 While that finding is consistent with the Wood study (and common sense), it is of limited value. Unlike Wood, however, Kennedy found that, at least in Dallas, plaintiffs tended to have more than de minimis stakes in the lawsuits: the value of corporate investments held by plaintiffs in the class/derivative and pure derivative suits ranged from $\$ 2000$ to over $\$ 100,000.54$

Regarding investigative sources for the litigation, Kennedy made some findings relevant to what he called the "dramatic event" idea. ${ }^{55}$ Nine of the fifty-six cases in his sample-not broken down here by class or derivativeinvolved SEC proceedings in the background, and fifteen related to bankruptcy proceedings. ${ }^{56}$ With some consolidation of related cases, these figures indicate that about half of the cases were inspired by either the SEC or bankruptcy, and half had sources that were not determined but were presumably initiated by attorneys and clients without aid of prior investigation or adjudication. ${ }^{57}$ Moreover, while the data on the incidence of litigation also treat class and derivative actions together, it is worth noting that, although the number of class or derivative actions increased somewhat from 1966 to 1973 , the ratio of individual securities actions to class or derivative actions remained fairly constant at about four to one. ${ }^{58}$

Finally, the study provides some useful information and some interesting suggestions on the issue of settlements. Derivative suit settlements appeared to be larger than class action settlements and tended to be handled with more procedural safeguards, such as notice prior to settlement. ${ }^{59}$ Class/derivative actions, moreover, tended to be treated in practice as derivative actions. ${ }^{60}$ The suggestion by Kennedy is that the courts' attitudes account for these differences, since the Dallas judges seem to have been much more hostile to class actions than to derivative litigation. ${ }^{61}$

Twenty settlements were reported in the class/derivative and pure derivative actions. ${ }^{62}$ In twelve of the thirteen settlements for which the terms were available, the estimated dollar value of the settlement in favor of the corporation ranged from $\$ 90,000$ to $\$ 6,000,000$; attorney fees varied from a

52. Id. .

53. Id. at 800 .

54. Id. at 819-20.

55. Id. at 807 .

56. Id. at 809 .

57. Id. at 824

58. Id. 801 (table 1), 802 .

59. Id. at 803-04.

60. Id. at 818 .

61. Id. at 803 .

62. Id. at 820 . 
low of $\$ 10,000$ to a high of $\$ 300,000$, with the lawyers' share ranging from five percent to thirty-three percent of the recovery. ${ }^{63}$ The six settlements with individual plaintiffs in pure class actions range from $\$ 2000$ to $\$ 60,000 .{ }^{64}$ Kennedy concluded simply that the settlements seemed to be reasonable, and that in any event plaintiffs in derivative actions fared better than those in class actions. ${ }^{65}$

The Kennedy study, as we shall explain below, is necessarily limited by its concentration on measurable outcomes, such as results and attorney fees. Moreover, the sample size is quite small, and the legal context of the federal district court in Dallas may be unique. Furthermore, as Kennedy emphasized, several important outcomes were not reported, and we do not know who ultimately bore the expense of even the reported settlements. Finally, the focus of the study on class actions inevitably limits the utility of its findings for an understanding of the derivative action. Some problems unique to the derivative suit were simply not addressed.

\section{The Jones Study (1980)}

Jones studied the involvement in class actions and shareholder derivative suits of 190 publicly held corporations sampled from the 1975 Fortune lists of the nation's largest companies. ${ }^{66}$ Jones published his results in two parts. The first concerned the incidence of class and shareholder derivative suits, their variation over time, and the relationship between the size of the corporation and the incidence of such suits. ${ }^{67}$ Summarizing the findings in this part, he found that "large firms, especially very large ones, have had more extensive experience with shareholder suits than have smaller firms," 68 but that even for large firms the average timing of "events" giving rise to shareholder litigation was but once every 11.9 years. ${ }^{69}$ Also, contrary to popularly held belief, there was "no striking increase in the incidence of these suits over the eight-year period [from 1971 to 1978]."70 Whatever the problems with class and derivative suits, he concluded, these data, applicable to both, do not lend much urgency to any call for reform. ${ }^{71}$

The second part of the Jones study ${ }^{72}$ found that over seventy-five percent of the 348 shareholder derivative and class action lawsuits in his sample resulted in "some relief" for the class or corporation. ${ }^{73}$ Only two of the

63. Id. .

64. Id. at 821 .

65. Id. .

66. Jones, An Empirical Examination of the Incidence of Shareholder Derivative and Class Action Lawsuils, 1971-1978, 60 B.U.L. Rev. 306, 308 \& nn.10-12, 326 app. A, 328 app. B (1980).

67. Id. at 307 .

68. Id. at 317 .

69. Id. .

70. Id. at 321 .

71. Id. at 325.

72. Jones, An Empirical Examination of the Resolution of Shareholder Derivative and Class Action Lawsuits, 60 B.U.L. REv. 542 (1980).

73. Id. at 545 (relief includes settlement, compliance, or favorable judgment). 
eighty-eight cases fully litigated, however, ended in judgment for the plaintiffs, and the extent of success in the 246 settlements cannot be ascertained objectively. ${ }^{74}$ Again, unfortunately, the aggregate data are not divided among class, class/derivative, and derivative suits.

What may be more helpful, however, is the detail Jones provided about fifty-five settlements, involving 228 suits. $^{75}$ Since class and derivative suits often differ as to both the nature of the allegations and the relief obtained, it can be ascertained roughly which suits were treated as derivative. ${ }^{76}$ Accordingly, of the thirty-two settlements that appear to be derivative, twenty resulted in quantifiable cash relief, most of it substantial; two involved an indeterminate monetary relief, and ten involved no monetary relief. ${ }^{77}$ Jones also listed the attorney fees where available, and fifteen of the twenty-four cases with fees reported appear to be derivative suits. ${ }^{78}$ The fees in the settlements for monetary relief ranged widely, but only three were for more than twenty-five percent of the amount of monetary relief, and three were for less than twenty percent. ${ }^{79}$ Questions remain, however, concerning the six settlements that resulted only in "procedural changes"; attorney fees in those cases ranged from $\$ 25,715$ to $\$ 85,000.80$ In contrast to most of the cases in the Wood sample, settlements in these more recent cases required both court approval and disclosure to shareholders. ${ }^{81}$ Accordingly, as Professor Conard has pointed out, the need by the lawyers and courts for a "paper trail" is much greater today than in the 1940's. ${ }^{82}$

Jones concluded with an optimistic evaluation of class and shareholder litigation. Yet the examination of outcomes, even if narrowed to those of shareholder derivative suits, is by no means decisive. Others certainly could differ on how to evaluate the data reported on settlements and attorney fees. After all, one-third of the total reported settlements involved no monetary relief, and six of the fifteen cases in which attorney fees were reported involved only "procedural changes" but significant attorney fees. Jones found specifically that the procedural changes reportedly made in response to litigation were quite useful, but others could suggest that they represented merely cosmetic changes-a paper trail-to induce court approval of

74. Id.

75. See id. at 547-5 I (40 setclements of determinate monetary value, involving 193 suits); id. at 556.57 ( 5 settlements of indeterminate monetary value, involving 21 suits); id. at 558.59 (10 settlements for nonmonetary relief, involving 14 suits).

76. "Derivative actions" was used to designate suits in which the cause of action was clearly derivative (e.g., improper payment), the recovery was to the corporation, or other derivative recovery was specified.

77. See Jones, supra note 72. In table III, id. at 548-51, numbers $3,7,10,14,15,19,22,24-30$, $32,33,36-38$, and 40 were treated as derivative; in table IV, $i d$. at 557 , numbers 2 and 5 were treated as derivative; and in table $V$, id. at 559, numbers $1-10$ were treated as derivative.

78. See id. at 565-66 (table VI).

79. See id. at 559 (table V).

80. Id. at 566 .

81. Rule 23.1 (enacted in 1966); see supra note 7 and accompanying text.

82. Memorandum from A.F. Conard to Bryant Garth (April 3, 1984) [hereinafter cited as Memorandum]. 
essentially improper settlements. ${ }^{83}$ Similarly, even the specific monetary recoveries cannot be evaluated objectively, as Jones points out. The information is helpful, but it does not enable us to determine if too few or too many shareholder derivative actions are being brought and settled.

\section{The Banoff and DuVal Study (1984)}

Banoff and DuVal conducted a two-part study of securities class and derivative litigation in the Southern District of New York. ${ }^{84}$ While the second part, focusing on the charge that class actions force defendants to settle even nonmeritorious claims, may be more germane to the highlighted concerns of this article, some of the insights and data in the first part, discussing the burdens placed on courts, add to the emerging picture of derivative actions. Again, the class action was the primary target for the authors' investigation. This focus inevitably affects the research approach, but here the authors have been careful to distinguish class, derivative, and class/derivative litigation.

The analysis is based on all securities cases involving a request for monetary relief which were filed in the Southern District of New York-in which, by the authors' estimate, “approximately one-third of the private securities cases in the nation were brought" 85 between July 1,1966 , and June $30,1973.86$ These cases were tracked to June $30,1978 .{ }^{87}$ Interviews with attorneys then supplemented the analysis of records, although some logistical difficulties limited that aspect of the study.

This study uncovered about two thousand securities lawsuits that remained in the district court, which the authors divided into cases and "entities" made up of related cases treated together: sixty percent of the cases were individual suits, eighteen percent derivative, eight percent class/derivative, and fourteen percent class. ${ }^{88}$ Consistent with the Jones study, there was no substantial increase in the incidence of such litigation over the period covered. ${ }^{89}$ On the question Kennedy raised earlier about the relationship between class and derivative suits, Banoff and DuVal analyzed the pleadings and reached the following conclusion: "class and derivative actions are fundamentally different types of litigation, serving different functions."90

Without elaborating on the sophisticated discussion of the burdens imposed on the courts, the findings most notable here were that section $16(\mathrm{~b})^{91}$ (insider trading) cases "terminated relatively quickly," 92 but that

83. Cf. Coffee, Rescuing the Private Attorney General: Why the Model of the Lawyer as Bounty Hunter is Not Working, 42 MD. L. Rev. 215, 237, 245 (1983); Conard, Winnowing Derivative Suits Through Attorneys Fees, Law \& Contemp. Probs., Spring 1984, at 269.

84. Banoff \& DuVal, The Class Action as a Mechanism for Enforcing the Federal Securities Laws: An Empirical Study of the Burdens Imposed, 31 WAYNE L. Rev. 1 (1984).

85. Id. at 37.

86. Id. at $37-39$.

87. Id. at 38 n. 108 .

88. Id. at 60 (table 6).

89. Id. at 67 (table 7); see supra text accompanying note 70.

90. Id. at 49 .

91. Securities Exchange Act of 1934, $\$ 16(b), 15$ U.S.C. $\S 78 p(b)$ (1982).

92. Banofl \& I) Val, supra note 84, at 56 . 
otherwise derivative cases were generally at least as burdensome as class actions. The real burdens imposed by class actions result mainly from "cases brought as class actions that would not have been brought."'93 The question that then becomes crucial for both types of litigation is whether the burdens are justifiable. ${ }^{94}$ Again, the concern is how to evaluate this means of regulation-through-litigation.

\section{E. Accomplishments and Limits of the Empirical Studies}

These empirical studies, taken together, provide a body of useful information about the derivative action. To summarize briefly, the data suggest that the number of cases is not increasing notably. Indeed, there may not be any more such cases now than in the 1930's and 1940's, when proportionately more derivative suits were presumably brought in state courts. The burden on federal courts is certainly much greater now; but that increased burden is not disproportionate to the growth of securities litigation in federal courts generally, and, of course, there are now many more class actions for damages after the 1966 revision of Rule 23. Moreover, the number of suits per corporation does not appear very large. Finally, we are now beginning to learn the nature of the burdens that derivative and class suits impose on courts and judges. While comparisons are risky because of the limitations of the individual studies and the noncomparability of the variable measures, the stakes of the plaintiff appear relatively greater today than during the period surveyed by Wood. Plaintiffs typically fare better today than in the past, with many fewer dismissals and more settlements involving gains to the corporation. While Wood's 1944 study found gains to the corporation in fewer than ten percent of the cases, Jones, in 1980, found gains in over seventy-five percent of the cases. Attorney fees do not appear today to constitute a great percentage of the recovery in most cases, although substantial fees certainly do continue to be allocated to plaintiffs' attorneys.

Unfortunately, the data only obliquely address certain fundamental concerns. For example, it is evident that more potential shareholder suits are now winnowed out prior to filing than in the 1930's and 1940's, ${ }^{95}$ but we cannot say how many potential cases might have been meritorious. More generally, the available studies cast little light on how crucial decisions are made to bring a derivative suit or to settle it on specific terms. Indeed, we do not even have much useful anecdotal data on the plaintiffs' securities bar. ${ }^{96}$

Similarly, we know little about the fairness or propriety of settlements and attorney fee awards in derivative actions. It would be useful to know what benefits have been obtained and fees awarded, but we still cannot say whether

93. Id. at 120 .

94. See id. at 128 .

95. See Conard, supra note 83.

96. More information is available concerning the antitrust bar. See, e.g. In re Fine Paper Antitrust Litig., 98 F.R.D. 48 (E.D. Pa. 1983) (data on the antitrust bar collected by Judge McGlynn); Coffee, supra note 83, at 252-61 (data used to explore the workings of the plaintiffs' antitrust bar). 
too much or too little was gained for the corporation and the attorneys. ${ }^{97}$ We can only speculate at this point about broad questions such as whether derivative actions can deter illegal corporate behavior ${ }^{98}$ and whether any such deterrence justifies the cost. The analysis of settlements and outcomes, in short, necessarily provides only a limited perspective on the derivative suit.

\section{III}

\section{Empirical Research: The Range of Questions and Research Designs}

Our review of extant empirical research on shareholder derivative suits reveals a focus on only a few of the wide range of possible questions that might be addressed. The studies reviewed in part II are concerned primarily with the incidence of cases filed, the allegations made, and the results, including the terms of any settlement and the size of the attorney fee award. While these questions are important and require more research and elaboration, they represent only one kind of agenda for the empirical study of derivative suits.

Anyone familiar with the literature on derivative suits can easily construct a very long list of questions on which further empirical research would be useful. Moreover, it is not difficult to expand that list to encompass broader questions of law, economy, and social policy. Obviously the issues surrounding the derivative suit are closely connected to more general themes concerning the regulation of corporate behavior, the capacity of courts, and the nature of the legal profession. Our concern here, however, is to address the narrower issues relating to efforts to assess the derivative suit's ability to fulfill more or less given functions. Such specific issues can be examined fruitfully according to numerous potential research designs.

Different social science disciplines tend to favor different designs, although the past two decades have witnessed a useful and productive crossfertilization of techniques. Moreover, as a result of eclecticism and the added confidence that comes from results provided by triangulation of method-the use of multiple methods to collect and analyze data-it is now considered good form to draw simultaneously on new developments in experimentation (contributed largely by psychologists), in cost-benefit analysis (contributed largely by economists), and in a variety of forms of survey research (contributed largely by sociologists). To date, however, efforts to study derivative suits have been confined almost exclusively to survey research.

97. See generally Batista, Counsel Fees in Derivative Litigation: End of the Golden Harvest?, 11 SEC. REg. L.J. 153 (1983) (analyzing what courts examine in determining whether an attorney fee request is reasonable); Mowrey, Altorney Fees in Securities Class Action and Derivative Suits, 3 J. CorP. L. 267 (1978) (discussing legal basis for awarding fees as well as the guidelines a court adopts in determining the size of the fee award).

98. See Brendle v. Smith, 46 F. Supp. 522, 525-26 (S.D.N.Y. 1942) (discussing the shareholder derivative suit's regulatory effect on corporate governance). 
There are at least four potential approaches to empirical research of the derivative action. Each approach addresses different aspects of the current debate and could lead to rather different insights. Under optimal conditions, an empirical study of derivative suits might include these four approaches, as well as others. Depending on available resources and particular interests, however, a more limited strategy might be elected.

The four design strategies we consider here are: (1) a cost/benefit analysis of the purposes of derivative suits and the degree to which these purposes are served; (2) a process and outcome study, using interview and archival record survey data, to assess the process by which derivative suits are initiated, handled, and decided, the outcomes of the suit, the impact on corporate behavior, and the relationship between processual factors and particular outcomes; (3) an observation study-participant or nonparticipant-of special litigation committees, examining the procedural and decisionmaking activities of such committees (complemented by a simulation study, using, for example, retired corporate executives and judges, to serve as a comparative data base for committee decisions); and (4) an experimental or quasi-experimental study of the relative merits of standing litigation committees versus specially selected committees, and committees composed of insiders versus those staffed by outsiders. This study would also consider the desirability of abolishing derivative suits for duty of care cases.

\section{A. Cost-Benefit Study}

The first approach, a cost-benefit study, ideally could answer what for many are the crucial questions: What specifically are the manifest and latent purposes of the shareholder derivative suit? To what extent does the derivative suit in fact serve ends of deterrence, ${ }^{99}$ or compensation, ${ }^{100}$ neither, or both?101 To what extent does the derivative suit serve as an effective mechanism for ensuring corporate accountability? The evaluation of effectiveness ultimately turns on the costs and benefits that can be attributed to the shareholder derivative suit, and a proper evaluation must be comparative. ${ }^{102}$ Moreover, one might ask whether other measures, such as

99. See Coffee \& Schwartz, supra note 3, at 307, 326-27 (recognizing that a derivative action may be an effective deterrent in the context of due care violations, where potential gain to disloyal officials is greatly exceeded by potential liability). But see Comment, supra note 5, at 894-902 (concluding that it is doubtful that the derivative suit deters managers from wrongdoing).

100. See Cox, supra note 18, at 990 (purpose of the derivative suit historically has been compensation). See generally id. at 989-94.

101. See Comment, supra note 5, at 877-902 (nonempirical cost-benefit analysis of the derivative suit concluding that the costs outweigh the benefits).

102. In small corporations, particularly those that are not subject to the complete disclosure regime of the Exchange Act, market forces are likely to operate very irregularly. Memorandum, supra note 82. See generally Securities Exchange Act of $1934 \$ \S 12(\mathrm{~g}), 15(\mathrm{~d}), 15$ U.S.C. $\S 78 l$ (1982). There are about 4000 corporations listed on exchanges, with specialists designated to watch them; there are another 4000 reporting regularly to the $\mathrm{SEC}$; there are $2,500,000$ more that are ouside of these regimes. No study will be worth much that does not distinguish between classes of corporations in its observations and its conclusions. Memorandum, supra note 82. 
incentive compensation contracts, ${ }^{103}$ managerial labor markets, ${ }^{104}$ and takeovers, ${ }^{105}$ are available and more cost-effective than shareholder litigation.

Traditional econometric cost-benefit models, which have become increasingly sophisticated, could be used to specify the contribution made by derivative suits. Unfortunately, costs and benefits are not particularly easy to quantify. ${ }^{106}$ A model must isolate and measure not only the contribution to specific deterrence of those who are chastened by a lawsuit, but also the general deterrence to those who merely perceive a threat of sanction. We confess to some skepticism about the reliability and validity of results from this approach, due to the difficulties in specifying acceptable models, valid assumptions about the range of costs and benefits, and appropriate measurement.

\section{B. A Process and Outcome Study}

A second approach would remain in the general tradition of those studies that have already been conducted, but the inquiry could be expanded beyond measurable outcomes to include processual factors. This approach would be similar in design to a study on class action litigation which these authors are currently conducting. ${ }^{107}$ In the specific context of derivative suits the effort would be to combine the data obtained from archival records with detailed information, obtained primarily from interviews with lawyers and representatives or other parties, about the processes which take some of the potentially huge number of shareholders' grievances and through litigation produce one or another outcome. Under this approach, outcome is defined not just in terms of a result in court, but also in terms of the impact on corporate behavior.

More specifically, it is important to learn from a substantial sample of cases and interviews how the potential or actual grievance is transformed into a dispute; how the dispute finds its way to a lawyer; how the lawyer and plaintiff shareholder are recruited; relevant characteristics of the plaintiff, the lawyers, and the corporate defendants; how and on what basis the decision is made to file a derivative suit; what is sought by the lawsuit; how key decisions, such as the decision to settle on specific terms, are made, on what basis, and by whom; the particular outcomes in terms of the amount of recovery, if any, and attorney fees; who pays the judgment-individuals, the corporation, or insurance; and how insurance is paid for and premiums are set. ${ }^{108}$

103. See, e.g., Baiman, Agency Research in Managerial Accounting: A Survey, 1 J. Acct. LrT. 154 (1982).

104. See, e.g., Fama, Agency Problems and the Theory of the Firm, 88 J. Pol. Econ. 288 (1980).

105. See, e.g., Manne, Mergers and the Market for Corporate Control, 73 J. PoL. Econ. 110 (1965).

106. For a thoughtful discussion, see Conard, supra note 83 . For rejection of the possibility of the enterprise, see Kelman, Trashing, 36 Stan. L. REV. 293, 938 (1984).

107. See Garth, Nagel \& Plager, Dispute Transformation and the Dynamics of Legal Representation in Class Action Litigation (National Science Foundation SES 82-18926) (publication pending).

108. See Memorandum, supra note 82. 
This set of descriptive data should enhance our picture of the derivative suit. An analytic part of the study might examine the relationships between a variety of processual factors and particular outcomes. For example, one could monitor the relationship between the source of the case (governmental investigation, lawyer investigation, actual shareholder dispute), the financial stake of the plaintiff, the amount alleged to be in controversy, the presence or absence of some form of special litigation committee, the presence or absence of defendant insurance, and outcomes such as size of settlement and award of attorney fees. A substantial sample of cases would produce patterns that might illuminate how derivative suits are processed and what results are obtained. Moreover, while it will remain difficult to ascertain when meritorious suits are foregone, which filed suits are "strike suits," 109 and which settlements are in some sense "collusive," an understanding of how and on what basis decisions are made in derivative litigation, coupled with correlations between processual factors and results, should shed new light on those questions.

These problematic questions might lead to another arena for empirical inquiry which could supplement the more general study. The decisions of three groups appear to be pivotal in the operation of the derivative suit-the derivative plaintiffs' bar, the corporations' boards of directors, and special litigation committees that evaluate derivative litigation. Some additional insight could be gained by interviewing and empirically studying certain aspects of these groups.

Professors Coffee and Schwartz suggest that the driving force in the derivative suit is the plaintiffs' counsel. ${ }^{110}$ Strong anecdotal evidence further indicates that some characteristics of the plaintiffs' antitrust bar encourages filing of certain lawsuits and selection of particular litigation strategies."11 Moreover, as noted, the Wood study found a heavy concentration of derivative litigation in relatively few law firms. ${ }^{112}$ It might therefore be instructive to investigate the background of lawyers representing plaintiffs in derivative litigation; the extent and character of a plaintiffs' derivative suit bar; the number of cases filed per lawyer or per law firm; the source of cases; the pattern of results; the fees generated, and the role of fees in negotiating settlements; the firms' economic structure and operation-how dependent they are on this litigation, for example; how important quick settlements are; and how decisions are made to "invest" in various stages of litigation. ${ }^{13}$ This

109. See Scott, supra note 2, at 942 (defining a strike suit as "an unwarranted action brought by an attorney in order to be bought off for a sum that is less than the costs of defense"). For a discussion of the classic strike suit, see Note, Extortionate Corporate Litigation: The Strike Suit, 34 Colum. 1. Rr.. 1308 (1934).

110. See Coffee \& Schwarty, supra note 3, at 316

111. See In re Fine Paper Antitrust Litig., 98 F.R.D. 48 (E.D. Pa. 1983); Coffee, supra note 83; Dul'al, The (Ilass Action as an Antitrust Enforcement Device: The Chicago Experience (Parts 1 \& 2), 1976 Ам. B. FOI'ND. RFsraRCH J. 1021, 1271.

112. See supra text accompanying note 33 .

113. The theme of "litigation as an investment process" is developed in Trubek, Sarat, Felstincer, Kritzer \& Grossman, The Costs of Ordinary Litigation, 31 UCLA L. REv. 72 (1983). 
information would dramatically improve our understanding about the economic incentives that motivate plaintiffs' lawyers and what litigation strategies can be expected.

Similarly, it might be helpful to focus more attention on the board of directors. Presumably the decisionmaking process of derivative defendant corporations could be ascertained as part of the general "process-outcome," but working backward from results of filed cases omits a critical and debated aspect of corporate decisionmaking as influenced by the derivative action. Can we, to the extent that deterrence is a purpose served by the derivative suit (as premised in the ALI Restatement Draft ${ }^{114}$ ), find concrete evidence that self-dealing and other illegal behavior are in fact deterred by the threat of a shareholder's suit? Is there evidence of specific or general deterrence, or both? 115 Is the deterrent effect a function of perceived certainty or severity of negative consequences, or both? ${ }^{16}$ And, to the extent that there is evidence of deterrence, how, by whom, and to whom is the deterrent message transmitted? Finally, are what would otherwise be legitimate business decisions "over-deterred" by the fear that litigation will result?

These questions can be addressed to corporate decisionmakers, but it might be difficult to assess the reliability of the responses. Nevertheless, to the extent that responses can be tied to specific incidents and relatively neutral reporting of events, useful data might be obtained. For example, inquiries about knowledge of derivative suits, sources of the knowledge, and its relevance in specific decisions could be helpful. Similarly, it would be interesting to know the number of times a potential derivative cause of action arises in day-to-day corporate discussions or communications from counsel, even if the inferences to be drawn from such knowledge might be somewhat speculative.

A third group that seems to be worth special attention is the special litigation committee, 117 which, however constituted, is charged with evaluating derivative suits on the corporation's behalf. So much of the current literature and case law revolves around this relatively new development that it is important to develop research strategies to test some of the positions that have been taken. One should be especially skeptical here, however, about the possibilities of simple interviewing or archival research, since the key questions concern the independence and judgment of such groups. The third and fourth approaches described in this article offer alternative means for studying these committees.

114. See generally Principles of Corporate Governance and Structure: Restatement and Recommendations $\$ 2.01$ comment C (Tent. Draft No. 1, 1982).

115. See generally D. Chambers, Making Fathers Pay: The Enforcement of Child Support 107 (1979); Barnet, The Deterrent Effect of Capital Punishment: A Test of Some Recent Studies, 29 Operations Research 346 (1981) (analogous statistical problems in isolating cause and effect due to large systematic error).

116. Sep sources cited supra note 115.

117. We employ the terminology of Cox, supra note 18. 


\section{Participant and Nonparticipant Observer Studies of Special Litigation Committees}

\section{A careful evaluation of special litigation committees would attempt to answer the following questions:}

(a) How are members of special litigation committees chosen? 118 What is the nature of their occupational backgrounds? 19 How many persons typically serve on a given committee?

(b) How is the "independence" of members established? That is, what are the criteria by which independence is measured? 120 To what extent are members free from economic, psychological, or family ties to corporate executives? ${ }^{121}$ Do committee members identify with the corporate board so as to begin with a presumption in favor of the defendants, or do they adopt a measurably neutral stance? 122

(c) How is the special counsel to the committee chosen? What is his or her legal experience? What is his or her relationship to corporate management? Is there a discernible pattern of having so-called "pro-management" counsel serving on more than one special litigation committee? Conversely, is there a discernible group of persons "not pro-management," who never get asked to serve again?123

(d) In what percentage of derivative suits that involve a special litigation committee is the committee appointed prior to the filing of the suit, as opposed to being appointed after the filing for only the case at hand? ${ }^{124}$ How many of the major companies have standby special litigation committees?

(e) For purposes of determining whether the suit is in the best interests of the corporation, what constitutes an "investigation?"125 What factors does the committee consider in reaching its judgment? 126 How does the committee evaluate

118. See Brown, Shareholder Derivative Litigation and the Special Litigation Committee, 43 U. PrTr. L. REv. 601, 619 (1982) (board of directors appoints the special litigation committee).

119. "Typically, the board of directors will select for membership on the committee individuals of independent business stature who have established reputations for being able to deal effectively with complicated business problems." Id. at 623 ; see $i d$. at $623 \mathrm{n} .88$ for case citations.

120. Coffee and Schwartz offer the following as potential measures of independence: "a majority of non-management directors, an independent nominating committee, adequate staff, and the absence of a controlling stockholder." Coffee \& Schwartz, supra note 3, at 301. These are, however, criteria by which one could judge the collective independence of the committee rather than the independence of its individual members. See Scott, supra note 2, at $934 \mathrm{n} .30$ (paraphrasing the ALI definition of independence as " 'free of any significant relationships' (as defined) with the corporation's senior executives"). But cf. Cox, supra note 18, at 1007-08 (criticizing this definition for neglecting "structural bias," which may be caused by other factors and is a "more subtle malady").

121. See, e.g., Dent, The Power of Directors to Terminate Shareholder Litigation: The Death of the Derivative Suit?, 75 Nw. U.L. Rev. 96, 125-26 (1980); Brown, supra note 118, at 626.

122. See Note, Special Litigation Committees: An Unwelcome Solution to Shareholder Demands, 1981 U. ILL. L. REV. 485, 506-08 (discussing pressures on "disinterested" directors to favor defendants); $c f$. Cox \& Munsinger, supra note 29, at 103-04.

123. Coffee and Schwartz suggest that some counsel gain a reputation as "friendly" while others are identified as "lough." Coffee \& Schwartz, supra note 3, at 323 n.329; see also Dent, supra note 121 , a) $117-18$ (role of special counsel for minority directors).

124. Coffee and Schwartz suggest, albeit with qualification, that a committee whose existence predates the litigation may develop a critical mass level of independence. Coffee \& Schwartz, supra note 3 , at 323 n.327.

125. See Dent, supra note 121 , at 120, 128-29.

126. The Court in Auerbach held that courts may inquire into the committee's selection of investigative procedures, but may not, absent a showing of bad faith, inquire into the committee's choice and weighing of factors after the conclusion of the investigation. Auerbach $v$. Bennett, 74 N.Y.2d 619, 633-34, 393 N.E.2d 994, 1002, 419 N.Y.S.2d 920, 928-29 (1979). 
legal, ethical, commercial, public relations, and fiscal grounds to determine whether the suit should be dismissed? ${ }^{127}$ In cases charging self-dealing, what procedures are followed to determine the financial terms of the transaction, whether there has been disclosure and independent approval of the transaction, and whether the transaction advances corporate interests?

(f) In what percentage and types of cases that involve a special committee does the committee find the suit not in the best interests of the corporation and recommend termination? ${ }^{128}$ If no net financial loss to the corporation results from alleged director malfeasance, may the special litigation committee nonetheless recommend that the derivative suit be continued?

(g) How do predominantly "insider" committees differ from predominantly "outsider" committees in terms of: membership composition; pre-inquiry values favoring the plaintiff, the defendants, or neither; procedures for handling the investigation; length of the inquiry; factors considered in reaching a judgment; and the outcome of the deliberative process? ${ }^{129}$

(h) What changes do committee members recommend aside from discontinuance of the suit? Would these changes, if any, have come about if no suit had been filed? ${ }^{130}$

Two distinct but complementary research strategies might initially be suggested to address these questions. First, knowledgeable participant observers might be employed. For example, a small group of recently retired corporate executives could be assigned to sit in as observers on a sample of cases where special litigation committees will be taking action. They could follow these cases from start to finish, recording their observations. Interviews with the actual corporate executives and committee members could then supplement the observations by answering questions related to the basis for committee appointment, the degree of financial independence of committee members, and the like. It might be possible to compare committees that have been constituted in different ways, such as by appointment from among the existing board members as contrasted with reaching out to external sources for persons who have no connection with the board. While the threshold problem with this kind of study is generally that of obtaining consent to be present, the special litigation committee may offer a unique opportunity for observation. One practical problem in evaluating this research would be the potential effect of the observer's presence on the process; however, since the observer's impact here presumably would lead the committee to be more "independent," at least that impact would be benign.

A simulation study could be used to evaluate committee deliberations. It might be feasible, for example, to assemble a group of recently retired corporate executives to serve as the "committee," and a retired judge to serve as "special counsel," and to simulate committee decisions in order to

127. See Dent, supra note 121 , at 129-30.

128. Cox noted in 1982 that "although there have been more than a score of special litigation committee cases to date, in all but one the committee concluded that the suit in question was not in the corporation's best interests." Cox, supra note 18, at 963.

129. Cf., e.g., Dent, supra note 121, at 111-17 (discussing director independence).

130. Memorandum, supra note 82 (suggesting that committees also "recommend changes in procedures, resignation of certain officers or directors, additions of new officers and directors, and even some sort of 'voluntary' restitution-while recommending that the suit be discontinued"). 
compare the process and outcome of their deliberations with those of the actual committees. These data might be particularly useful to debates about inherent structural bias: who makes the committee appointments, committee independence, the degree of independence as a function of the selection process, and characteristics of those selected.

\section{Experimental and Quasi-Experimental Approaches}

The potential for experimental or quasi-experimental inquiry ${ }^{131}$ may be illustrated with two examples, the first of which continues the assessment of special litigation committees. A researcher might seek to test which of the variety of compositions of such committees works "best." One approach would be a modified version of Campbell and Stanley's now classic Posttestonly Control Group Design. ${ }^{132}$ Assuming one could define, in acceptably measurable terms, factors indicating when "the shareholders' best interests are better served," one would, for example, randomly assign derivative suit cases to inside or outside committees ${ }^{133}$ and, if possible, standing or newlyappointed committees. The four possible combinations-insider/standing, insider/newly-appointed, outsider/standing, and outsider/newly-appointedcould then be compared using accepted measures of the extent to which "shareholders' best interests are better served," to determine which structure is most effective.

One difficult problem in executing such a study would be the specification of valid and reliable measures to reflect the construct "shareholders' best interests are better served." Another might be securing the cooperation of corporations to be randomly assigned to the use of one of the four structural combinations. Should this latter problem prove insurmountable, one might modify the design by substituting, for the random assignment, the selection of corporations whose committee structures fit each of the four hypothesized combinations. If one could determine that the corporations did not differ from each other in other relevant ways, this would be a good compromise design.

Another hypothesis to be approached experimentally might be Professor Scott's assertion that little would be lost by the abolition of derivative suits for "duty of care" cases. ${ }^{134}$ To study the potential impact of abolishing derivative suits in duty of care cases, one might use Campbell and Stanley's Multiple

131. For a review of experimental and quasi-experimental design in legal research, see Lempert, Strategies of Research Design in the Legal Impact Study: The Control of Plausible Rival Hypotheses, LAw \& Soc'y Rev., Nov. 1966, at 111 . For a review of the same in the context of evaluation research, see Nagel \& Sheldon, Methods of Evaluative Research, in Social Science Methodology (R. Smith ed. 1982).

132. See Campbell \& Stanley, Experimental and Quasi-Experimental Designs for Research on Teaching, in Handbook of Research in Teaching 204 (N. Gage ed. 1963).

133. See Scott, supra note 2, at 934. Scott argues generally that while the question as to the effectiveness of insider versus outsider committees is empirical, and has yet to be resolved, the ALI Restatement, supra note 28, presumes the outsider committee is preferred. This preference is contrary to the thesis in Fama, supra note 104, that inside directors have more incentive to monitor effectively because of the impact of the outcomes on their personal careers.

134. See Scott, supra note 2, at 937. 
Time Series Design or, perhaps, the Non-Equivalent Control Group Design. ${ }^{135}$ Under ideal circumstances, some state would decide to abolish, effective at a future date, derivative suits for duty of care cases. In the Multiple Time Series Design, one would devise a set of potential impact measures. These might include the hypothesized effects put forth by Scott: risk-averse decisionmaking by the board, savings in litigation expense and insurance premiums, and simplification of the legal system in this field. ${ }^{136}$ These impact measures would be observed over time before the experiment began both for the state abolishing the cause of action and for a comparable state not making such a change. The observations would continue for a period of time after the abolition occurred, again both for the state making the change and for the comparison state. If Scott's hypothesis is correct, there should be no change in the recorded observations for the comparison state but a notable change in observations for the state that abolished derivative suits for duty of care cases. ${ }^{137}$ The Non-Equivalent Control Groups Design builds on the same logic of comparisons but dictates a single beforeand-after measure rather than the series of repeated before-and-after measures dictated by the Multiple Time Series Design.

Even if one or more states should decide to abolish the derivative cause of action, there remain potential difficulties with this kind of study. For example, some plaintiffs might allege a federal cause of action as a substitute for bringing a state court suit based on duty of care. To the extent that such substitution occurs, Scott's hypotheses could not be tested validly with these designs. Nevertheless, scholars should be alert to changes in state law which might lend themselves to before-and-after or comparative study.

\section{IV}

\section{Limits of Empirical Research: A Conclusion}

The approaches sketched here supply only the beginnings of a research strategy; questions of sample selection, measurement, and modes of data analysis have been omitted. Of course other strategies are also possible and different questions may seem to other researchers to be equally or more important. In our conclusion, however, we would prefer to address some larger questions about the contribution that social science approaches might make generally. ${ }^{138}$

First, all of the methodologies suffer inevitably from serious limitations and even possibilities for bias. In addition to some of the problems already mentioned, there are natural tendencies for interviewers to listen particularly for responses that coincide with already held opinions and for persons being

135. See Campbell \& Stanley, supra note 132.

136. See Scott, supra note 2, at 937.

137. Alternatively, the observations could change in similar ways for the two states before $X$, the experimental event, but differently after $X$.

138. See generally Macaulay, Law and the Behavioral Sciences: Is There Any There There?. 6 LAw \& POL'Y Q. 149 (1984). 
interviewed either to remember events and couch responses in ways that correspond with their current interests and opinions or to respond to "cues" provided by the interviewer. Careful interviewing can minimize these risks, but obviously cannot eliminate them.

Second, even if the empirical findings are valid, they may not resolve debates about the derivative suit. Research might show, for example, that most derivative suits are brought by shareholders with a realistic expectation of winning and that settlements represent genuine benefits for the corporation that justify the costs incurred through the litigation. It might still be suggested, however, that other ways of regulating management behavior are preferable or that "over-deterrence" chills business decisions that would contribute to economic growth.

It might be shown, on the other hand, that the derivative suit bar shops for plaintiffs and files numerous suits hoping only that some portion will result in fee-generating settlements. Nevertheless, a supporter of derivative suits might discount these findings and suggest that the current process leads to the filing of at least some meritorious suits, helps keep management in line, and is better than any proposed alternative. A similar challenge could be made to special litigation committees which determine costs and benefits only from the perspective of the corporation. Even if shown to be quite fair and independent, they may discourage some potentially meritorious litigation and may reduce the general deterrent impact that is supposed to result from derivative litigation. Supporters and opponents of the derivative suit might have to shift ground when confronted with carefully collected data, but they would not necessarily change their minds.

Finally, there is another more subtle limitation to any of the approaches described in this article. We have relied in this study on recent scholarly literature to characterize the purposes and functions of derivative litigation. It might be useful, on the other hand, to approach those purposes and functions from a broader social perspective. ${ }^{139}$ If, as we suggested at the outset, the real question is about controlling economic power, then we ought to recognize that the derivative suit represents a complex social institution that helps to regulate power conflicts. It provides, for example, one more or less accessible outlet, with potentially important symbolic value, ${ }^{140}$ for persons otherwise unhappy with corporate actions, such as decisions to pay bribes in the Third World. ${ }^{141}$ The availability of this particular outlet in some way determines how such disaffection will be expressed and it also helps to prevent the channeling of dissent into other, perhaps more disruptive outlets.

139. "[S]erious scholarship must push outward beyond the 'boundaries' of what we call the legal system if the goal is to describe and analyze the place of law in society." Id. at 179 (emphasis in original).

140. See supra text accompanying note 1 . The assertion that the derivative suit is "the chief regulator of corporate management" certainly appears to be an exaggeration.

141. See Dusenberg, The Business Judgment Rule and Shareholder Derivative Suits: A View From the Inside, 60 WASH. U.L.Q. 311, 326-29 (1982). 
A research design intended to reach these issues would have to go beyond those we have described.

A sensitivity to such fundamental issues in law and society could help to inform any research perspective, but the suggestions in this article are more modest. Before we explore any hidden roles of the derivative suit in our society, we ought to expand our knowledge about how it works concretely and how it might work if reformed in certain ways. While the results of empirical research will inevitably be subject to challenges on methodological grounds, and research alone cannot in any event resolve all the debates, further systematic investigation offers considerable potential to move the debate beyond all-too-familiar and unsubstantiated assumptions. 
